\title{
Asesmen Tingkat Pemahaman Penyelenggara Jalan Kota Terhadap Kriteria Green Roads Construction Di Kota Payakumbuh Tahun 2019
}

\author{
Adria Sari ${ }^{1}$, Yossyafra ${ }^{2}$, Bayu Martanto Adji ${ }^{3}$ \\ ${ }^{1}$ Fakultas Teknik, Universitas Andalas ${ }^{1,2,3}$ \\ email: adriasari@gmail.com ${ }^{1}$ yossyafra@ft.unand.ac.id ${ }^{2}$ bayumartantoadji@ymail.com ${ }^{3}$ \\ DOI: http://dx.doi.org/10.31869/rtj.v3i2.1782
}

\begin{abstract}
Abstrak: Prasarana jalan merupakan salah satu faktor penting dalam pertumbuhan suatu daerah, baik ekonomi, pembangunan maupun perkembangan sosial. Berdasarkan data pada tahun 2018, Pemerintah Kota Payakumbuh melalui Dinas Pekerjaan Umum dan Penataan Ruang mengelola lebih dari $250 \mathrm{~km}$ jalan kota. Pengelolaan tersebut berupa perbaikan, peningkatan maupun pemeliharaan jalan yang semuanya tak lepas dari kegiatan konstruksi yang tentunya akan memberikan dampak positif dan dampak negatif yang cukup besar. Untuk meminimalkan dampak negatif tersebut maka diperkenalkanlah konsep green road construction. Penerapan konsep tersebut didalam pelaksanaan konstruksi tentunya tidak terlepas dari kebijakan yang dikeluarkan oleh pemerintah. Untuk itu perlu dilakukan suatu penelitian tentang seberapa baiknya tingkat pemahaman penyelenggara jalan pada Pemerintah Kota Payakumbuh terhadap konsep green road construction tersebut. Kriteria yang dipergunakan dalam penelitian adalah kriteria yang yang dikeluarkan oleh Kementrian Pekerjaan Umum dan Perumahan Rakyat melalui surat edaran Menteri nomor 04/SE/M/2018 tahun 2018 tentang pedoman pemeringkatan jalan hijau sedangkan metode analisa yang dipergunakan untuk penilaian tingkat pemahaman adalah metode Severity Index. Hasil penelitian menunjukkan bahwa tingkat pemahaman penyelenggara jalan untuk kategori konservasi lingkungan air, udara dan alam cukup paham, untuk kategori transportasi dan masyarakat tidak paham, kategori aktivitas pelaksanaan konstruksi dan kategori material dan sumber daya alam adalah paham sedangkan untuk kategori teknologi perkerasan adalah sangat paham.
\end{abstract}

Kata kunci : Green road construction, pelaksana jalan, pemahaman, Severity Index.

\section{PENDAHULUAN}

Prasarana jalan merupakan salah satu urat nadi dalam pertumbuhan ekonomi wilayah. Jalan mempunyai peranan yang sangat penting dalam memperlancar perekonomian, mendukung perkembangan sosial dan memperlancar pembangunan suatu daerah sehingga taraf hidup masyarakat akan meningkat. Berdasarkan data pada tahun 2018, Pemerintah Kota Payakumbuh melalui pejabat pelaksana jalan mengelola lebih dari $250 \mathrm{~km}$ jalan kota diluar pembangunan jalan baru. Dampak positif yang timbul pada aspek ekonomi dan sosial tidak demikian halnya dengan dampak yang timbul terhadap lingkungan. Peningkatan pertumbuhan panjang jalan telah menimbulkan dampak negatif terhadap lingkungan. Dampak negatif tersebut antara lain adalah berkurangnya ketersediaan sumber daya alam sebagai pembentuk struktur jalan, meningkatnya jumlah limbah yang dihasilkan oleh proses konstruksi, meningkatnya emisi yang ditimbulkan pada tahap pembangunan maupun operasional, berkurangnya lahan produktif akibat pengalihan lahan akibat pembangunan jalan, dan berbagai dampak lain terkait dengan lingkungan baik secara langsung maupun tidak langsung.

Salah satu usaha yang dapat dilakukan untuk mengatasi dampak negatif tersebut adalah dengan mewujudkan konsep keberlanjutan dalam industri konstruksi yaitu dengan penerapan konsep jalan hijau untuk konstruksi jalan atau dikenal dengan istilah green road construction. Dalam hal ini pemerintah telah mengeluarkan beberapa kebijakan dalam bentuk Peraturan Menteri antara lain Peraturan Menteri Nomor 10/PRT/M/2008 tentang Penetapan Jenis Rencana Usaha dan Kegiatan Bidang Pekerjaan Umum yang Wajib Dilengkap dengan Upaya Pengelolaan Lingkungan dan Upaya Pemantauan Lingkungan, Keputusan Direktorat Jenderal Bina Marga Nomor : 08, 09, 10, 11 Tahun 2009 tentang Pedoman Umum, Pedoman Perencanaan, Pedoman Pelaksanaan dan Pedoman Pemantauan 
Pengelolaan Lingkungan Hidup Bidang Jalan dan Jembatan, Peraturan Menteri Pekerjaan Umum Nomor : 19/PRT/M/2011 tentang Persyaratan dan Perencanaan Teknis Jalan, Peraturan Menteri Pekerjaan Umum Nomor : 05/PRT/M/2012 tentang Pedoman Penanaman Pohon pada Sistem Jaringan Jalan, Peraturan Menteri Pekerjaan Umum dan Perumahan Rakyat Nomor : 05/PRT/M/2015 tentang Pedoman Umum Implementasi Konstruksi Berkelanjutan pada Penyelenggaraan Infrastruktur Bidang Pekerjaan Umum dan Permukiman.

Pemahaman penyelenggara jalan dalam hal ini Dinas Pekerjaan Umum dan Penataan Ruang Kota Payakumbuh mengenai konsep green road construction harus dikaji secara mendalam karena pemerintah merupakan pihak yang memegang peranan penting dalam mewujudkan terlaksananya green road construction.

\section{METODE PENELITIAN}

Metode analisis yang dipilih dalam penelitian ini adalah Metoda Severity Index. Strategi yang digunakan adalah dengan menentukan variabel penelitian, melakukan tahapan pengumpulan data, analisis data, kesimpulan dan saran. Variabel yang digunakan dalam penelitian ini mengacu kepada surat edaran Menteri nomor 04/SE/M/2018 tahun 2018 tentang pedoman pemeringkatan jalan hijau.

Severity Index dihitung dengan mengunakan rumus Abd. Majid dan McCaffer (1997) sebagai berikut :

$$
\begin{gathered}
\text { Severity Index }(\mathrm{SI})=\left(\frac{\sum_{\mathrm{i}=1}^{5} \Sigma_{1} x_{1}}{5 \sum_{1}^{5} x_{1}}\right) \\
\ldots \ldots \ldots(\text { persamaan } 1)
\end{gathered}
$$

Keterangan :

$\mathrm{SI}=$ Severity Index

$\alpha_{i} \quad=$ skor jawaban berdasarkan skala likert

$x_{\hat{i}} \quad=$ jumlah frekuensi responden

Severity Index dari keseluruhan indikator dihitung berdasarkan skor setiap responden. Nilai maksimum dari Severity Index yaitu 1 yang berarti paham dan nilai minimum yaitu 0,0 yang berarti tidak paham. Skala tingkat pemahaman ditentukan dengan interval 0,2. Hal ini dapat dilihat pada gambar 1 di bawah ini.

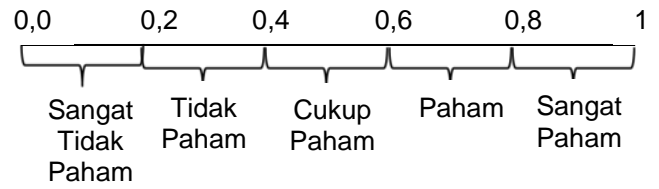

Gambar 1. Skala tingkat pemahaman

$$
S I=\frac{\sum_{i=0}^{4} a i x i}{4 \sum_{i=0}^{4} x i}(100 \%)
$$

Dimana :

$$
\begin{aligned}
& \text { ai }=\text { Konstanta Penilaian } \\
& \mathrm{Xi}=\text { Probabilitas responden } \\
& \mathrm{I}=0,1,2,3,4, \ldots, \mathrm{n} \\
& \text { Xo = probabilitas responden "sangat } \\
& \text { tidak paham", maka ao }=0 \\
& \mathrm{X} 1=\text { probabilitas responden "tidak } \\
& \text { paham", maka a1 = } 1 \\
& \mathrm{X} 2=\text { probabilitas responden "cukup } \\
& \text { paham", maka a2 }=2 \\
& \text { X3 = probabilitas responden "paham", } \\
& \text { maka a3 = } 3 \\
& \mathrm{X} 4=\text { probabilitas responden "sangat } \\
& \text { paham", maka a } 4=4
\end{aligned}
$$

Adapun klasifikasi skala penilaian pada probabilitas adalah sebagai berikut :

Sangat tidak paham (STP)

$$
=0,000 \leq \mathrm{SI}<20,00
$$

Tidak paham (TP)

$$
=20,00 \leq \mathrm{SI}<40,00
$$

Cukup paham $(\mathrm{CP})$

Paham (P)

$$
=40,00 \leq \mathrm{SI}<60,00
$$

Sangat paham (SP)

$$
=80,00 \leq \mathrm{SI}<100,00
$$

Kategori, sub kategori dan indikator yang digunakan dalam penelitian ini dapat dilihat pada table 1 di bawah ini.

\begin{tabular}{|l|c|c|}
\hline \multicolumn{1}{|c|}{ KATEGORI } & $\begin{array}{c}\text { Jumlah } \\
\text { Subkategori }\end{array}$ & $\begin{array}{c}\text { Jumlah } \\
\text { Indikator }\end{array}$ \\
\hline 1. Konservasi lingkungan, air, udara dan alam & 9 & 29 \\
\hline 2. Transportasi dan masyarakat & 8 & 21 \\
\hline 3. Aktifitas pelaksanaan konstruksi & 10 & 11 \\
\hline 4. Material dan sumber daya alam & 6 & 6 \\
\hline 5. Teknologi perkerasan & 10 & 10 \\
\hline TOTAL & $\mathbf{4 3}$ & $\mathbf{7 7}$ \\
\hline
\end{tabular}

Tabel 1. Tabel Kategori, Subkategori dan Indikator 


\section{HASIL DAN PEMBAHASAN}

Responden yang terpilih merupakan pelaksana jalan kota di instansi Dinas Pekerjaan Umum dan Penataan Ruang Kota Payakumbuh. Jumlah responden untuk penelitian ini adalah sebanyak 5 responden. Responden merupakan sebagai pengambil kebijakan/sebagai pejabat di instansi Dinas Pekerjaan Umum dan Penataan Ruang Kota Payakumbuh. Berikut adalah data demografi responden terpilih.

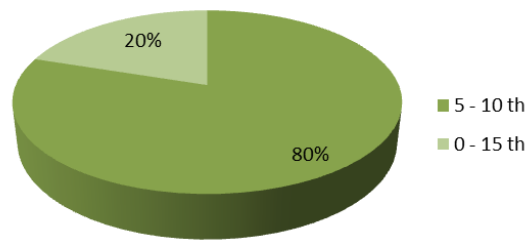

Gambar 2. Diagram lama pengalaman kerja responden

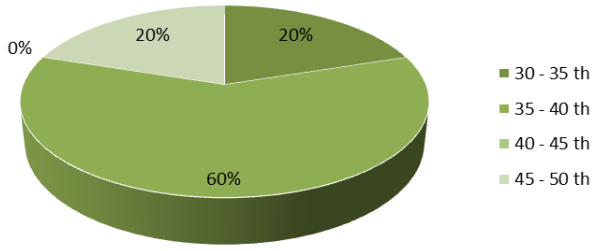

Gambar 3. Diagram Usia responden

\section{a. Penilaian kategori konservasi lingkungan air, udara, dan alam}

Hasil penilaian kategori konservasi lingkungan air, udara, dan alam dapt dilihat pada tabel 2 berikut:

\begin{tabular}{|l|c|c|c|c|}
\hline \multicolumn{5}{|c|}{ Bobot Pemahaman } \\
\hline RSP 1 & RSP 2 & RSP 3 & RSP 4 & RSP 5 \\
\hline & & & & \\
\hline 56,222 & 21,502 & 49,525 & 22,026 & 52,011 \\
\hline & & & & \\
\hline
\end{tabular}

Tabel 2. Rangkuman nilai responden untuk kategori konservasi lingkungan, air, udara dan alam

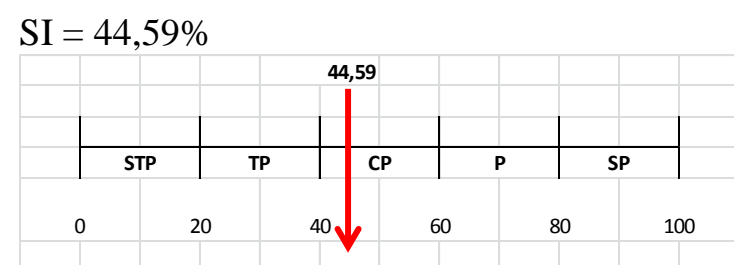

Gambar 4. Tingkat Pemahaman Responden Untuk Kategori Konservasi Lingkungan Air, Udara dan Alam

b. Penilaian Kategori Transportasi dan Masyarakat

Hasil penilaian kategori Transportasi dan Masyarakat dapat dilihat pada tabel 3 berikut:

\begin{tabular}{|c|c|c|c|c|}
\hline \multicolumn{5}{|c|}{ Bobot Pemahaman } \\
\hline RSP 1 & RSP 2 & RSP 3 & RSP 4 & RSP 5 \\
\hline & & & & \\
\hline 51,020 & 26,664 & 24,672 & 16,084 & 42,456 \\
\hline & & & & \\
\hline
\end{tabular}

Tabel 3. Rangkuman nilai responden untuk kategori Transportasi dan Masyarakat

$$
\begin{aligned}
& \mathrm{SI}=\frac{a_{0} \cdot x_{0}+a_{1} \cdot x_{1}+a_{02} \cdot x_{2}+a_{3} \cdot x_{3}+a_{4} \cdot x_{4}}{4\left(x_{0}+x_{1}+x_{2}+x_{3}+x_{4}\right)}(100 \%) \\
& \mathrm{SI}=37,025
\end{aligned}
$$

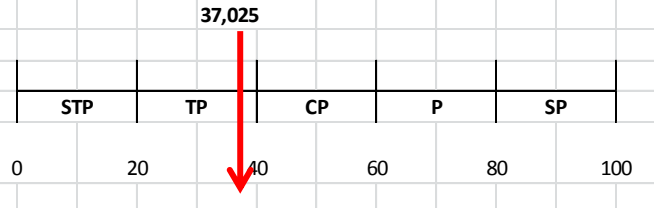

Gambar 5. Tingkat Pemahaman Responden Untuk Kategori Transportasi dan Masyarakat

\section{c. Penilaian Kategori Aktivitas Pelaksanaan Konstruksi \\ Hasil penilaian kategori Aktivitas Pelaksanaan Konstruksi dapat dilihat pada tabel 4 berikut:}

\begin{tabular}{|c|c|c|c|c|}
\hline \multicolumn{5}{|c|}{ Bobot Pemahaman } \\
\hline RSP 1 & RSP 2 & RSP 3 & RSP 4 & RSP 5 \\
\hline & & & & \\
\hline 71,399 & 41,347 & 40,207 & 34,266 & 65,026 \\
\hline & & & & \\
\hline
\end{tabular}

Tabel 4. Rangkuman nilai responden untuk kategori Aktivitas pelaksanaan konstruksi

$$
\mathrm{SI}=\frac{a_{0} \cdot x_{0}+a_{1} \cdot x_{1}+a_{02} \cdot x_{2}+a_{3} \cdot x_{3}+a_{4} \cdot x_{4}}{4\left(x_{0}+x_{1}+x_{2}+x_{3}+x_{4}\right)}(100 \%) \mathrm{SI}=\frac{a_{0} \cdot x_{0}+a_{1} \cdot x_{1}+a_{02} \cdot x_{2}+a_{3} \cdot x_{3}+a_{4} \cdot x_{4}}{4\left(x_{0}+x_{1}+x_{2}+x_{3}+x_{4}\right)}(100 \%)
$$


$\mathrm{SI}=60,12$

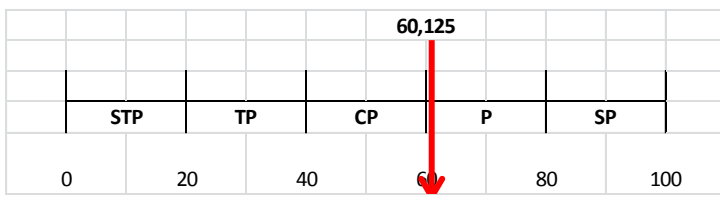

Gambar 6. Tingkat Pemahaman Responden Untuk Kategori Aktivitas pelaksanaan konstruksi

\section{d. Penilaian Kategori Material dan Sumber Daya Alam}

Hasil penilaian kategori Material dan Sumber Daya Alam dapat dilihat pada tabel 5 berikut:

\begin{tabular}{|c|c|c|c|c|}
\hline \multicolumn{5}{|c}{ Bobot Pemahaman } \\
\hline RSP 1 & RSP 2 & RSP 3 & RSP 4 & RSP 5 \\
\hline & & & & \\
\hline 100,000 & 55,105 & 27,391 & 55,105 & 27,391 \\
\hline & & & & \\
\hline
\end{tabular}

Tabel 5. Rangkuman nilai responden untuk kategori Material dan Sumber Daya Alam

$\mathrm{SI}=\frac{a_{0} \cdot x_{0}+a_{1} \cdot x_{1}+a_{02} \cdot x_{2}+a_{3} \cdot x_{3}+a_{4} \cdot x_{4}}{4\left(x_{0}+x_{1}+x_{2}+x_{3}+x_{4}\right)}(100 \%)$

$$
\mathrm{SI}=63,70
$$

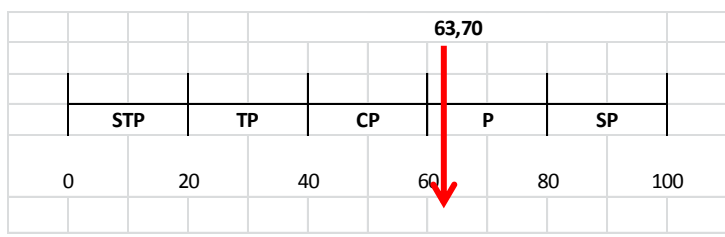

Gambar 7. Tingkat Pemahaman Responden Untuk Kategori Material dan Sumber Daya Alam

\section{e. Penilaian Kategori Teknologi Perkerasan \\ Hasil penilaian kategori Teknologi Perkerasan dapat dilihat pada tabel 6 berikut:}

\begin{tabular}{|c|c|c|c|c|}
\hline \multicolumn{5}{|c}{ Bobot Pemahaman } \\
\hline RSP 1 & RSP 2 & RSP 3 & RSP 4 & RSP 5 \\
\hline & & & & \\
\hline 91,816 & 15,743 & 78,813 & 33,592 & 91,406 \\
\hline & & & & \\
\hline
\end{tabular}

Tabel 6. Rangkuman nilai responden untuk kategori Teknologi Perkerasan

$\mathrm{SI}=\frac{a_{0} \cdot x_{0}+a_{1} \cdot x_{1}+a_{02} \cdot x_{2}+a_{3} \cdot x_{3}+a_{4} \cdot x_{4}}{4\left(x_{0}+x_{1}+x_{2}+x_{3}+x_{4}\right)}(100 \%)$

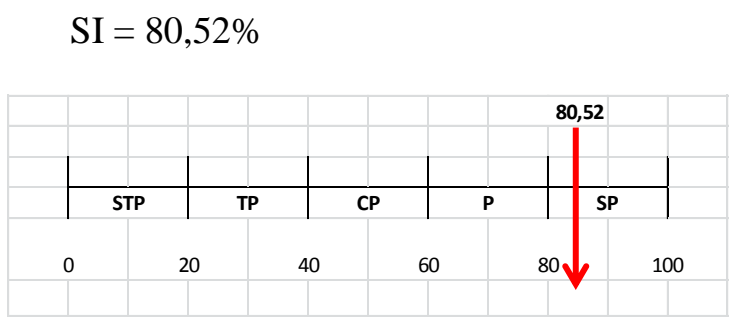

Gambar 8. Tingkat Pemahaman Responden Untuk Kategori Teknologi Perkerasan

Berdasarkan nilai Severity Index yang telah didapatkan dari hasil analisis di atas, maka tingkat pemahaman penyelenggara jalan terhadap konsep green road construction dapat dilihat pada tabel 7 di bawah ini.

\begin{tabular}{|l|c|c|}
\hline \multicolumn{1}{|c|}{ KATEGORI } & Nilai & $\begin{array}{c}\text { Tingkat } \\
\text { Pemahaman }\end{array}$ \\
\hline \begin{tabular}{l|c|} 
1. Konservasi lingkungan, air, udara \\
dan alam
\end{tabular} & 44,59 & Cukup Paham \\
\hline 2. Transportasi dan masyarakat & 37,02 & Tidak Paham \\
\hline 3. Aktifitas pelaksanaan konstruksi & 60,12 & Paham \\
\hline 4. Material dan sumber daya alam & 63,7 & Paham \\
\hline 5. Teknologi perkerasan & 80,52 & Sangat Paham \\
\hline
\end{tabular}

Tabel 7. Tingkat Pemahaman

Penyelenggara Jalan terhadap konsep green road construction

\section{PENUTUP}

Sesuai dengan perumusan masalah dan tujuan penelitian serta hasil yang didapatkan melalui analisis berdasarkan pengumpulan dan pengolahan data yang telah dilakukan maka dapat diambil kesimpulan antara lain :

1. Tingkat pemahaman penyelenggara jalan untuk jalan kota pada Dinas Pekerjaan Umum dan Perumahan Rakyat Kota Payakumbuh mengenai Green Road Construction untuk 
kategori konservasi lingkungan air, udara dan alam adalah cukup paham.

2. Tingkat pemahaman penyelenggara jalan untuk jalan kota pada Dinas Pekerjaan Umum dan Perumahan Rakyat Kota Payakumbuh mengenai Green Road Construction untuk kategori transportasi dan masyarakat adalah tidak paham

3. Tingkat pemahaman penyelenggara jalan untuk jalan kota pada Dinas Pekerjaan Umum dan Perumahan Rakyat Kota Payakumbuh mengenai Green Road Construction untuk kategori aktivitas pelaksanaan konstruksi adalah paham

4. Tingkat pemahaman penyelenggara jalan untuk jalan kota pada Dinas Pekerjaan Umum dan Perumahan Rakyat Kota Payakumbuh mengenai Green Road Construction untuk kategori material dan sumber daya alam adalah paham

5. Tingkat pemahaman penyelenggara jalan untuk jalan kota pada Dinas Pekerjaan Umum dan Perumahan Rakyat Kota Payakumbuh mengenai Green Road Construction untuk kategori Teknologi Perkerasan adalah sangat paham

\section{DAFTAR PUSTAKA}

Kementerian Pekerjaan Umum dan Perumahan Rakyat.(2015). Peraturan Menteri Pekerjaan Umum dan Perumahan Rakyat No.05 /PRT/M/2015 tentang Pedoman Umum Implementasi Konstruksi Berkelanjutan pada Penyelenggaraan Infrastruktur Bidang Pekerjaan Umum dan Permukiman. Berita Negara RI Tahun 2015, No. 430. Menteri Pekerjaan Umum dan Perumahan Rakyat

Pusat Penelitian dan Pengembangan Jalan dan Jembatan (2018) Pedoman Pemeringkatan Jalan Hijau. Jakarta: Kementerian Pekerjaan Umum dan Perumahan Rakyat.

Greenroads Foundation. (2011). Greenroads Manual v1.5. Washington: Greenroads Foundation.

Faah, Karlina. J. (2017). Analisis Tingkat pemahaman Pemangku Kepentingan terkait peneranpan Konsep Jalan Berkelanjutan (Green Road) di Kota Kupang.Jurnal Infrastruktur, Juni 2007. Retrieved from https://bpsdm.pu.go.id/jurnal/articles/an alisis-tingkat-pemahaman-pemangkukepentingan-terkait-penerapan-konsepjalan-berkelanjutan-green-road-di-kotakupang

Mustofa, S. (2017). Studi Kesiapan dan hambatan Implemetasi Green Road Construction (Studi Kasus : Provinsi Sumatera Barat). Prosiding $4^{\text {th }}$ Andalas Civil Engineering (ACE) Conference 2017, 9 November 2017.Padang. Jurusan Teknik Sipil Universitas Andalas.

Lawalata, Greece. (2018). Usulan Indikator Jalan Berkelanjutan untuk Indonesia (Proposed Sustainable Road's Indicators For Indonesia). Jurnal Jalan Jembatan, Maret 2018. Retrieved from www.pusjatan.pu.go.id/jurnal.pusjatan.p u.go.id/index.php/jurnaljalanjembatan/ar $\underline{\text { ticle/view/71 }}$

Suprayoga, Gede B., Lawalata, Greece. (2015). Penentuan Bobot Aspek Penialaian Keberlanjutan dalam Pemeringkatan Jalan Hijau (Weighting Assesment Aspects For Sustainable Ability in Green Road Rating). Jurnal Jalan Jembatan Vol 32 No 3, Desember 2015. Retrieved from www.pusjatan.pu.go.id/jurnal.pusjatan.p u.go.id/index.php/jurnaljalanjembatan/ar ticle/view/174

Lawalata, Greece., Sailendra, Agus Bari., (2018). Pemeringkatan Jalan Hijau, Pemeringkatan Implementasi Konstruksi Berkelanjutan. Jurnal Jalan Jembatan, Mei 2018. Retrieved from

International Road Vederation. (2013). Moving Towards Green Road Infrastructure, Case Studies adn Lessons Learned. Retrieved from https://www.irfanet.ch>pdf-

files $>$ IRF_mowing_towards_green_road infrastructure

Tanesia, Randy K., Analisi Konsep Green Roads yang Berkelanjutan Terhadap Pemahaman Pemangku Kepentingan dalam Penerapan Manajemen Limbah 
Pada Proye Infrastruktur Jalan, https://ejournal.uajy.ac.id/8578/3/TS202160

Takim, Rosiana., Najwa, Fatin., Intan. (2015). Green Highway for Malaysia: A Literature Review. Retrieved from https://www.academia.edu/26117950/Gr een_Highway_for_Malaysia_A_Literatu re_Review

Evrianto, Wulfram I., Kajian Faktor Green Construstion Infrastruktur Jalan Berdasarkan Sistem Rating Green Road dan INVEST.

Adianto, Yohanes LD., Gunawan, Danu Tirta., Linna., Studi Pemahaman Penerapan Constructability Kontraktor di Bandung

Aritonang, L. R. (2005). Kepuasan Pelanggan, pengukuran dan Penganalisaan dengan SPSS. Jakarta : Gramedia Pustaka Utama.

Franzosi, R. (2008). Content Analysis : Objective, Systematic, and Quantitative Description of Content. California : Sage Publications. 